\title{
Optimization of Minituber Size and Planting Distance for the Breeder Seed Production of Potato
}

\author{
Md. Altaf Hossain ${ }^{1}$, Abdullah-Al-Mahmud², Md. Abdullah-Al-Mamun ${ }^{3}$, Md. Shamimuzzaman ${ }^{4}$, \\ Md. Mizanur Rahman ${ }^{5}$ \\ ${ }^{1}$ Tuber Crops Research Centre (TCRC), Bangladesh Agricultural Research Institute (BARI), Joydebpur, Gazipur, Bangladesh \\ ${ }^{2}$ International Potato Center (CIP), USAID Horticulture Project, Bangladesh \\ ${ }^{3}$ Department of Agriculture Extension (DAE), Rangpur, Bangladesh \\ ${ }^{4}$ Department of Crop Sciences, University of Illinois at Urbana-Champaign, Urbana, Illinois 61801, USA \\ ${ }^{5}$ Department of Horticulture, Bangabandhu Sheikh Mujibur Rahman Agricultural University, Joydebpur, Gazipur, Bangladesh
}

\section{Email address:}

Altafmy@yahoo.com (Md. A. Hossain), A.Mahmud@cgiar.org (Abdullah-Al-Mahmud), Mamun.dae@gmail.com (Md. Abdullah-Al-Mamun)

\section{To cite this article:}

Md. Altaf Hossain, Abdullah-Al-Mahmud, Md. Abdullah-Al-Mamun, Md. Shamimuzzaman, Md. Mizanur Rahman. Optimization of Minituber Size and Planting Distance for the Breeder Seed Production of Potato. American Journal of Agriculture and Forestry.

Vol. 3, No. 2, 2015, pp. 58-64. doi: 10.11648/j.ajaf.20150302.18

\begin{abstract}
Six grades of potato minitubers ( $<5 \mathrm{~mm}, 5-10 \mathrm{~mm}, 10-15 \mathrm{~mm}, 15-20 \mathrm{~mm}, 20-25 \mathrm{~mm}$ and $>25 \mathrm{~mm})$ and four planting distance $(25 \mathrm{~cm}, 20 \mathrm{~cm}, 15 \mathrm{~cm}$ and $10 \mathrm{~cm})$ with a potato variety Diamant were taken in an study during 2013-14 at the Tuber Crops Research Centre of Bangladesh Agricultural Research Institute, Gazipur, Bangladesh. The objective was to observe the effect of minituber grades and planting distance on growth, seed yield, increase ratio and seed potential of potato. The largest minitubers $(>25 \mathrm{~mm})$ planted at widest distance $(25 \mathrm{~cm})$ produced maximum number of tubers per plant $(18.7)$. The highest number of tubers per $\mathrm{m}^{2}$ (306.7) was obtained with largest minitubers $(>25 \mathrm{~mm})$ planted at the closest plant spacing $10 \mathrm{~cm}$, while it was lowest (64.0) in smallest size minituber $(<5 \mathrm{~mm})$ with the widest distance $25 \mathrm{~cm}$. A significant increase ratio was found ranged from 14 (largest minituber with the closest planting distance) to 297 (smallest minituber with widest planting distance). The maximum percentage (53\%) of 'A grade' seed (28-55mm size) was obtained from the pea size $(5-10 \mathrm{~mm})$ minituber size planted at $15 \mathrm{~cm}$ distance. The highest seed potential (39.8) was in $>25$ mm size minituber planted at $10 \mathrm{~cm}$ distance. The lowest (4.4) was in $<5 \mathrm{~mm}$ size minituber when planted at $25 \mathrm{~cm}$ distance. Seed sizes increasing from $<5$ $\mathrm{mm}$ to $>25 \mathrm{~mm}$ had significant increase ratio ranged from 12 to 269 . The highest economic return (9.4) would occur for the pea size $(5-10 \mathrm{~mm})$ minituber when planted at $15 \mathrm{~cm}$ spacing.
\end{abstract}

Keywords: Minituber, Breeder Seed and Potato

\section{Introduction}

Unavailability of certified seed tubers is a major constraint to potato production in Bangladesh. This compels most farmers to use planting materials from informal sources such as previous harvests from own field, local markets and neighbours. Bangladesh Agricultural Research Institute (BARI) has the national mandate to produce basic seed tubers (Breeder's seed) but can only supply less than $1 \%$ of the national requirements. BADC and other private seed potato producer can supply maximum 5\% quality seed (Hossain et al., 2008). It is recorded that in 2012-2013, BADC supplied 19,322 $\mathrm{M}$ tons of seed potato which is only $4.12 \%$ of total quality seed [1].
Minitubers are usually defined as the progeny tubers produced on in vitro derived plantlets [17]. The size of minitubers may range from $5-25 \mathrm{~mm}$ and a range in weight between 0.1-10 gm and sometimes higher. Larger mini-tubers also have become common ([8],[17]). Minituber production has significantly reduced the number of generations required to produce commercial seed potatoes. This has reduced exposure to pathogens during field multiplication, resulting in healthier tubers in seed crops. Experience in production of single-hill, first generation, seedling screening material in the variety development program has shown that minitubers as small as 1-2 g can produce viable productive plants [13]. The optimizing of plant density is one of the most important subjects of potato production, because, it affects to seed cost, 
plant development, yield, and quality of the crop [4]. In practice, plant density in potato crop is manipulated through the number and size of the seed tubers planted [3]. Widely spaced plants allow better separation at harvest to isolate tubers from individual hills. The low population provides individual plants an advantage in access to moisture, nutrients, and sunlight. To optimize production from prenucleus minitubers, plants populations should closely mirror populations typically used for seed production [16]. Therefore, many studies have been conducted to establish the optimal combination of seed size and planting distance for a certain environment ([18], [5], and [4].

A lot of research work has been done to evaluate the performance of potato seed tubers but little information exists on the field performance of minituber for the breeder's seed production of potato. Therefore, the present study was conducted to evaluate the field performance of different size potato minituber and planting distance for the production of breeder's seeds of potato.

\section{Materials and Methods}

\subsection{Site, Soil and Season of the Experiment}

The experiment was conducted at the net house of Tuber Crops Research Centre, BARI, Gazipur during November, 2013 to March 2014. The location of the experimental site was to the $34 \mathrm{~km}$ north from Dhaka city $\left(24.38^{0} \mathrm{~N}\right.$ latitude and $90.13^{\circ}$ longitudes) at $8.4 \mathrm{~m}$ above the sea level. The soil of the experimental field was grey terrace contained $\mathrm{pH} 6.4$. This area is moderately drought prone, and face drought both winter and late winter season. The experimental site is situated in a sub- tropical climate zone and characterized by no rainfall during December to March.

\subsection{Planting Materials and Date of Planting}

Diseases free well sprouted seed potato minitubers of Diamant variety were used as planting material for the experiment. Mini-tubers were planted on 6th November, 2013.

\subsection{Crop Management}

The field was ploughed 3-4 times to a depth of $25 \mathrm{~cm}$. Full doses of well rotten cow dung $\left(10 \mathrm{t} \mathrm{ha}^{-1}\right)$, TSP $\left(220 \mathrm{~kg} \mathrm{ha}^{-1}\right)$, MP (270 kg ha $\left.{ }^{-1}\right)$, Gypsum (120 kg ha-1), Boric acid (6 kg ha$\left.{ }^{1}\right)$ and half doses of Urea $\left(175 \mathrm{~kg} \mathrm{ha}^{-1}\right)$ were applied at the time of final land preparation. The rest half dose of Urea (175 $\mathrm{kg} \mathrm{ha}^{-1}$ ) was applied as side dressings at 30 DAP followed by earthing-up and light irrigation. First earthing up was done at 30 DAP when the plant attained a height of about $15-20 \mathrm{~cm}$ from the base, second earthing-up was done after 20 days of first earthing up. Before first earthing up, Urea was applied. Irrigation was applied 3 times. First one was applied just after planting, second one was just after earthing up at 30 DAP, and last one was on 55 DAP. During land preparation, Furadan 5G was applied @10 kg ha-1 as basal during land preparation and Admire $(0.2 \%)$ was sprayed in two installments at 45 and 60 DAP to control insects. The crops were also sprayed alternatively with Dithane-M 45 (0.2\%) and Secure $(0.1 \%)$ at 15 days interval to prevent the late blight infection of potato. The field was netted during the entire growing period to protect the plants from the insect infestation specially aphids which is the vector of different viruses. Seeds were planted at row distance of $60 \mathrm{~cm}$ row and planting distance of $25,20,15$ and $10 \mathrm{~cm}$. Haulm pulling was done at 75 DAP by hand. Hardening and setting up of skins of tubers were allowed for 10 days under the soil there after crop was harvested at 85 DAP. Tubers were collected carefully with the help of spade without any injury.

\subsection{Design and Treatments of the Experiment}

The experiment was laid out in two factors Randomized Complete Block Design (RCBD) with three replications. First of all the entire experimental field was divided into three blocks, representing three replications. Each block again divided into twenty four unit plots. The treatment was assigned randomly to unit plots of each block. The size of a unit plot was $3.0 \mathrm{~m} \times 2.4 \mathrm{~m}$. There were six grades of minitubers based on minituber diameter $\left(\mathrm{S}_{1} /\right.$ Under size $=<5$ $\mathrm{mm}, \quad \mathrm{S}_{2} /$ pea size $=5-10 \mathrm{~mm}, \quad \mathrm{~S}_{3} /$ small size $=10-15 \mathrm{~mm}$, $\mathrm{S}_{4} /$ medium size $=15-20 \mathrm{~mm}, \mathrm{~S}_{5} /$ large size $=20-25 \mathrm{~mm}$ and $\mathrm{S}_{6} /$ extra-large $=>25 \mathrm{~mm}$ ) based on minituber diameter and four planting distance $\left(D_{1}=25 \mathrm{~cm}, D_{2}=20 \mathrm{~cm}, D_{3}=15 \mathrm{~cm}\right.$ and $\mathrm{D}_{4}=15 \mathrm{~cm}$ ) which formed twenty four treatment combinations. Treatment combinations were as follows-

$\mathrm{S}_{1} \mathrm{D}_{1}, \mathrm{~S}_{1} \mathrm{D}_{2}, \mathrm{~S}_{1} \mathrm{D}_{3}, \mathrm{~S}_{1} \mathrm{D}_{4}, \mathrm{~S}_{2} \mathrm{D}_{1}, \mathrm{~S}_{2} \mathrm{D}_{2}, \mathrm{~S}_{2} \mathrm{D}_{3}, \mathrm{~S}_{2} \mathrm{D}_{4}, \mathrm{~S}_{3} \mathrm{D}_{1}, \mathrm{~S}_{3} \mathrm{D}_{2}$, $\mathrm{S}_{3} \mathrm{D}_{3}, \mathrm{~S}_{3} \mathrm{D}_{4}, \mathrm{~S}_{4} \mathrm{D}_{1}, \mathrm{~S}_{4} \mathrm{D}_{2}, \mathrm{~S}_{4} \mathrm{D}_{3}, \mathrm{~S}_{4} \mathrm{D}_{4}, \mathrm{~S}_{5} \mathrm{D}_{1}, \mathrm{~S}_{5} \mathrm{D}_{2}, \mathrm{~S}_{5} \mathrm{D}_{3}, \mathrm{~S}_{5} \mathrm{D}_{4}$, $\mathrm{S}_{6} \mathrm{D}_{1}, \mathrm{~S}_{6} \mathrm{D}_{2}, \mathrm{~S}_{6} \mathrm{D}_{3}$ and $\mathrm{S}_{6} \mathrm{D}_{4}$.

\subsection{Climatological Data}

Air temperature and humidity, precipitation, evaporation, soil temperature and ground water table were recorded throughout the crop period (Table 1).

Table 1. Climatological data of 2013-14 crop season.

\begin{tabular}{|c|c|c|c|c|c|}
\hline \multirow{2}{*}{ Month } & \multicolumn{3}{|c|}{ Air Temperature $\left({ }^{\circ} \mathrm{C}\right)$} & \multirow{2}{*}{ Humidity (\%) } & \multirow{2}{*}{ Rain Fall (mm) } \\
\hline & Max. & Min. & Av. & & \\
\hline \multicolumn{6}{|l|}{$2013-14$} \\
\hline November & 26.60 & 22.43 & 24.52 & 80.47 & 8.44 \\
\hline December & 19.90 & 15.45 & 17.68 & 89.05 & 0.00 \\
\hline January & 15.20 & 11.58 & 13.39 & 90.80 & 0.00 \\
\hline February & 23.85 & 19.08 & 21.47 & 89.89 & 8.43 \\
\hline March & 31.16 & 26.09 & 28.62 & 76.70 & 29.84 \\
\hline
\end{tabular}




\subsection{Data Collection}

Data on different growth and yield contributing characters were recorded from the sample plants of each plot during the course of experiment. The sampling was done randomly. The plants in the outer row were excluded during random selection. Five plants were randomly selected from each plot to record the data on the following parameters: Plant emergence, plant height, leaf area, number and weight of tubers per plant, yield $\left(\mathrm{kg} \mathrm{m}^{-2}\right)$, and percentage of different grades of tuber by number, seed potentials and seed increase ratio.

\subsection{Statistical Analysis}

To find out the significance of experimental results, the collected data on different parameters were analyzed statistically by using MSTAT-C program. The mean for all the treatments were calculated and analysis of variance for each parameter was performed by F-test. The mean separation was done by DMRT at 5\% level of probability.

\section{Results and Discussion}

\subsection{Plant emergence (\%)}

Analysis of variance indicated that the interaction effect of minituber size and planting distance had significant influence on emergence rate at 30 DAP (Table 2). The highest emergence rate was found in large minituber with $25 \mathrm{~cm}$ planting distance $(94.1 \%)$, which was statistically identical to other planting distance and extra-large. The lowest emergence rate $(61.8 \%)$ was obtained from under-size minituber at $10 \mathrm{~cm}$ planting distance, which was statistically at par with $15 \mathrm{~cm}$ planting distance $(62.7 \%)$. In an average emergence performance of the under-size minituber at any planting distance is very low compared to other sizes. These results support the findings of Rykbost and Charlton (2004); Karafyllidis et al. (1997) and El Amin et al. (1996).

Table 2. Interaction effect between minituber size and planting distance on percent plant emergence

\begin{tabular}{llllll}
\hline \multirow{2}{*}{ Minituber size } & \multicolumn{9}{l}{ Planting distance (cm) } & \multirow{2}{*}{ Mean } \\
\cline { 2 - 5 } & $\mathbf{2 5}$ & $\mathbf{2 0}$ & $\mathbf{1 5}$ & $\mathbf{1 0}$ & \\
\hline Under size & 69.9 & 68.9 & 62.7 & 61.8 & 65.8 \\
Pea & 79.4 & 75.8 & 77.8 & 78.2 & 77.8 \\
Small & 82.5 & 80.4 & 83.8 & 83.2 & 82.5 \\
Medium & 89.4 & 82.9 & 87.6 & 84.9 & 86.2 \\
Large & 94.1 & 89.2 & 90.5 & 91.4 & 91.3 \\
Extra-large & 91.1 & 89.4 & 88.1 & 88.8 & 89.4 \\
Mean & 84.4 & 81.1 & 81.8 & 81.4 & \\
LSD $(0.05)$ & & & & & \\
Planting distance (P) & 8.72 & & & & \\
Minituber size (M) & 7.99 & & & & \\
P x M & 21.35 & & & & \\
\hline
\end{tabular}

\subsection{Plant Height (cm)}

The tallest plant $(85.9 \mathrm{~cm})$ was produced by extra-large size minituber when planted at $25 \mathrm{~cm}$ distance; shortest $(50.2 \mathrm{~cm})$ plant was produced by under-size mintuber with $25 \mathrm{~cm}$ (Table 3). Jagroop et al. (1993) found taller plants with large size normal seed tubers planted at closer spacing. Probably the plant height was the highest in the larger size minituber due to the presence of more reserve food which caused rapid growth of plants earlier. Similar findings have also been reported by Zakaria (2003) but his research was on the effect different size of microtuber on plant height.

Table 3. Interaction effect between minituber size and planting distance on plant height $(\mathrm{cm})$

\begin{tabular}{llllll}
\hline \multirow{2}{*}{ Minituber size } & \multicolumn{9}{l}{ Planting distance $(\mathbf{c m})$} & \multirow{2}{*}{ Mean } \\
\cline { 2 - 5 } & $\mathbf{2 5}$ & $\mathbf{2 0}$ & $\mathbf{1 5}$ & $\mathbf{1 0}$ & \\
\hline Under size & 50.2 & 59.8 & 58.4 & 57.8 & 56.6 \\
Pea & 71.7 & 66.5 & 64.3 & 70.7 & 68.3 \\
Small & 65.7 & 68.7 & 62.0 & 67.7 & 66.0 \\
Medium & 70.4 & 69.5 & 65.5 & 70.7 & 69.0 \\
Large & 71.1 & 71.0 & 71.3 & 65.3 & 69.7 \\
Extra-large & 85.9 & 72.2 & 79.8 & 68.8 & 76.7 \\
Mean & 69.2 & 68.0 & 66.9 & 66.8 & \\
LSD $(0.05)$ & & & & & \\
Planting distance (P) & 2.97 & & & & \\
Minituber size (M) & 4.85 & & & & \\
P x M & 9.69 & & & & \\
\hline
\end{tabular}

\subsection{Leaf Area $\left(\mathrm{cm}^{2}\right)$}

Generally, yield was positively correlated to leaf area and was increased linearly as leaf area increased. Planting distance had significant difference on the leaf area production of plants derived from minituber (Table 4). Extra-large minituber contributed the highest leaf area values across all population density levels in comparison to other seed minitubers. The trend was such that the bigger the seed piece, the greater the leaf area. There was increase in leaf area with increase in minituber size and planting distance. The leaf area was highest in largest minituber with planting distance $25 \mathrm{~cm}$ but lowest in smallest mini-tuber with closest planting distance $10 \mathrm{~cm}$. These results are in conformity with the findings of Akhtar et al. (2010). Lower leaf area index and radiation interception in small seed size undoubtedly reduced production of assimilates.

Table 4. Interaction effect between minituber size and planting distance on leaf area

\begin{tabular}{llllll}
\hline \multirow{2}{*}{ Minituber size } & \multicolumn{7}{l}{ Planting distance (cm) } \\
\cline { 2 - 6 } & $\mathbf{2 5}$ & $\mathbf{2 0}$ & $\mathbf{1 5}$ & $\mathbf{1 0}$ & Mean \\
\hline Under size & 837.7 & 814.3 & 797.0 & 785.7 & 808.7 \\
Pea & 924.0 & 891.3 & 849.0 & 831.0 & 873.8 \\
Small & 966.0 & 948.3 & 933.7 & 912.0 & 940.0 \\
Medium & 1042 & 1031 & 1008 & 991.0 & 1018.0 \\
Large & 1233 & 1210 & 1173 & 1150 & 1191.5 \\
Extra-large & 1414 & 1385 & 1353 & 1280 & 1358.0 \\
Mean & 1069.5 & 1046.7 & 1019.0 & 991.6 & \\
LSD $(0.05)$ & & & & & \\
Planting distance (P) & 120.6 & & & & \\
Minituber size (M) & 130,2 & & & & \\
P x M & 124.8 & & & & \\
\hline
\end{tabular}




\subsection{Tuber Number per Plant and per $m^{2}$}

Minituber size and planting distance interacted significantly and affected the number of tuber per plant (Table $5 \& 6$ ). The tuber number per plant increased with increase in minituber size in each planting spacing. The extra-large minituber planted at widest distance $(25 \mathrm{~cm})$ produced maximum number of tuber per plant (18.7) which was statistically similar to $20 \mathrm{~cm}(18.0))$ and $10 \mathrm{~cm}$ (18.4) of same groups respectively. Number of tubers per plant was the lowest in smallest minituber with closest planting distance 10 $\mathrm{cm}$ (8.10). Larger minituber have higher amount of reserve food and interplant competition for space, light, water and nutrient is less in the wider spacing that can contribute the increase number of tuber per plant. The number of tubers per $\mathrm{m} 2$ was increased with increase in minituber size with closer planting distance (Table 16). The highest number of tuber per $\mathrm{m} 2$ was obtained with extra-large minitubers planted at the $10 \mathrm{~cm}$ distance (306.7), while it was lowest in under-size minituber with the widest distance $25 \mathrm{~cm}$ (64.0). The results were in conformity with the findings of Haverkort et al. (1991) who found increasing number of tubers per plant with increase in size of microtuber. The same information was reported by Rykbost and Charlton (2004) and Karafyllidis et al. (1997). These results are in conformity with the findings of Tuku (2000) who reported that higher yield was associated with proper nutrients and water availability to the plant and more tuber weight. Gopal et al. (2007) after conducting similar study also proposed that selection for tuber yield can be practiced at the minituber level in potato breeding processes. Zkaynak \& Samanci (2006) worked on field performance of three weight classes of small minitubers ranging from 6.0 - $18.0 \mathrm{~g}$ was studied in two years at different planting dates. The heavy minitubers gave higher values than light minitubers for tuber yield, tuber weight, tuber number and stem number.

Table 5. Interaction effect between minituber size and planting distance on tuber number per plant

\begin{tabular}{llllll}
\hline \multirow{2}{*}{ Minituber size } & \multicolumn{6}{l}{ Planting distance (cm) } \\
\cline { 2 - 6 } & $\mathbf{2 5}$ & $\mathbf{2 0}$ & $\mathbf{1 5}$ & $\mathbf{1 0}$ & Mean \\
\hline Under size & 9.6 & 9.6 & 10.8 & 8.1 & 9.5 \\
Pea & 11.5 & 12.9 & 10.3 & 10.0 & 11.2 \\
Small & 12.5 & 10.7 & 10.4 & 9.6 & 10.8 \\
Medium & 11.5 & 10.4 & 11.5 & 13.9 & 11.8 \\
Large & 13.1 & 14.8 & 13.7 & 15.7 & 14.3 \\
Extra-large & 18.7 & 18.0 & 14.4 & 18.4 & 17.4 \\
Mean & 12.8 & 12.7 & 11.9 & 12.6 & \\
LSD & & & & & \\
Planting distance (P) & 0.85 & & & & \\
Minituber size (M) & 1.40 & & & & \\
P x M & 2.09 & & & & \\
\hline
\end{tabular}

Table 6. Interaction effect between minituber size and planting distance on tuber number per $m^{2}$

\begin{tabular}{llllll}
\hline \multirow{2}{*}{ Minituber size } & \multicolumn{7}{l}{ Planting distance (cm) } \\
\cline { 2 - 6 } & $\mathbf{2 5}$ & $\mathbf{2 0}$ & $\mathbf{1 5}$ & $\mathbf{1 0}$ & Mean \\
\hline Under size & 64.0 & 84.8 & 120.8 & 151.0 & 105.2 \\
Pea & 76.4 & 114.1 & 114.0 & 166.7 & 117.8 \\
Small & 83.5 & 94.1 & 90.3 & 173.4 & 110.3 \\
Medium & 76.4 & 91.8 & 127.3 & 231.0 & 131.6 \\
Large & 87.1 & 130.7 & 152.4 & 262.1 & 158.1 \\
Extra-large & 124.5 & 158.9 & 160.0 & 306.7 & 187.5 \\
Mean & 85.3 & 112.4 & 127.5 & 215.2 & \\
LSD $(0.05)$ & & & & & \\
Planting distance (P) & 14.42 & & & & \\
Minituber size (M) & 18.28 & & & & \\
P x M & 7.57 & & & & \\
\hline
\end{tabular}

\subsection{Tuber Weight per Plant and per $m^{2}$}

Minituber size and planting distance interacted significantly and there was a significant influence on tuber weight per plant (Table $7 \& 8)$ ). Tuber yield per plant increased significantly with increase in minituber size and planting distance. The maximum tuber weight per $(985.0 \mathrm{~g})$ plant was obtained from the extra-large minituber with planting distance $25 \mathrm{~cm}$ and minimum tuber weight per plant $(119.0 \mathrm{~g})$ was found from the under-size minituber with closest planting distance $10 \mathrm{~cm}$ which was statistically similar to other spacing of the same size. Different trend was observed in weight of tuber per $\mathrm{m}^{2}$. The highest weight of tubers per $\mathrm{m}^{2}(8.50 \mathrm{~kg})$ was obtained from the largest minitubers with closest planting distance $10 \mathrm{~cm}$ which was at par with large size minituber with closest planting distance $10 \mathrm{~cm}(8.29 \mathrm{~kg})$. The lowest weight of tuber per $\mathrm{m} 2(0.99$ $\mathrm{Kg}$ ) was found in under-size with widest spacing $25 \mathrm{~cm}$.

Table 7. Interaction effect between minituber size and planting distance on tuber weight per plant $(g)$

\begin{tabular}{llllll}
\hline \multirow{2}{*}{ Minituber size } & \multicolumn{7}{l}{ Planting distance (cm) } \\
\cline { 2 - 6 } & $\mathbf{2 5}$ & $\mathbf{2 0}$ & $\mathbf{1 5}$ & $\mathbf{1 0}$ & Mean \\
\hline Under size & 148.4 & 147.2 & 126.0 & 119.4 & 135.3 \\
Pea & 719.6 & 641.0 & 615.7 & 469.7 & 611.5 \\
Small & 670.2 & 584.4 & 552.7 & 476.9 & 571.1 \\
Medium & 688.2 & 600.2 & 495.9 & 390.5 & 543.7 \\
Large & 811.1 & 757.6 & 651.7 & 497.3 & 679.4 \\
Extra-large & 985.0 & 831.3 & 694.9 & 509.9 & 755.3 \\
Mean & 670.4 & 593.6 & 522.8 & 410.6 & \\
LSD $(0.05)$ & & & & & \\
Planting distance (P) & 3.09 & & & & \\
Minituber size (M) & 3.88 & & & & \\
P x M & 7.57 & & & &
\end{tabular}


Table 8. Interaction effect between minituber size and planting distance on tuber yield $\left(\mathrm{kg} \mathrm{m}^{-2}\right)$

\begin{tabular}{llllll}
\hline \multirow{2}{*}{ Minituber size } & \multicolumn{7}{l}{ Planting distance(cm) } \\
\cline { 2 - 6 } & $\mathbf{2 5}$ & $\mathbf{2 0}$ & $\mathbf{1 5}$ & $\mathbf{1 0}$ & Mean \\
\hline Under size & 0.99 & 1.30 & 1.40 & 1.99 & 1.42 \\
Pea & 4.80 & 5.66 & 6.84 & 7.83 & 6.28 \\
Small & 4.47 & 5.16 & 6.14 & 7.95 & 5.93 \\
Medium & 4.59 & 5.30 & 5.51 & 6.51 & 5.48 \\
Large & 5.41 & 6.69 & 7.24 & 8.29 & 6.91 \\
Extra-large & 6.57 & 7.34 & 7.72 & 8.50 & 7.53 \\
Mean & 4.47 & 5.24 & 5.81 & 6.85 & \\
LSD (0.05) & & & & & \\
Planting distance (P) & 0.22 & & & & \\
Minituber size (M) & 0.27 & & & & \\
P x M & 0.53 & & & & \\
\hline
\end{tabular}

\subsection{Seed Potential}

From the calculation, the seed potentials of minituber of the different sizes planted at different spacing ranged from 4.4 to 39.8 (Table 9). The highest seed potential (39.8) was found in extra-large size minituber planted at $10 \mathrm{~cm}$ distance. The lowest seed potential (4.4) was in under-size minituber when planted at $25 \mathrm{~cm}$ distance. However, the yield (both number and weight per plant) of under-size and extra-large size minituber was negligible.

\subsection{Increase Ratio}

Results observed in this trial demonstrated that extremely high increases ratios as minituber size decreased and a large reduction in this ratio as minituber size increased (Table 9). Effects of increasing minituber size on yield are attributed to a combination of increases in both number and size of daughter tubers. Seed sizes increasing from under-size to extra-large size had significant increase ratio ranged from 12 to 269. Rykbost and Charlton (2004) reported 65 to 317 increase ratios from the minituber size ranged from $1.2 \mathrm{~g}$ to $13.6 \mathrm{~g}$. They also reported that a typical seed increase expectation is 15 or 20 to 1 but in the irrigated production, the increase ratio is likely to be 20 to 1 . The similar results were found by Masarirambi et al. (2012) and Islam et al. (2012).

Table 9. Interaction effect between minituber size and planting distance on seed potential and increase ratio

\begin{tabular}{|c|c|c|c|c|c|c|c|c|}
\hline \multirow{3}{*}{ Minituber size } & \multicolumn{4}{|c|}{ Seed potential } & \multicolumn{4}{|c|}{ Increase ratio } \\
\hline & \multicolumn{4}{|c|}{ Planting distance (cm) } & \multicolumn{4}{|c|}{ Planting distance $(\mathrm{cm})$} \\
\hline & 25 & 20 & 15 & 10 & 25 & 20 & 15 & 10 \\
\hline Under size & 0.99 & 1.30 & 1.40 & 1.99 & 130 & 119 & 93 & 72 \\
\hline Pea & 4.80 & 5.66 & 6.84 & 7.83 & 269 & 223 & 210 & 155 \\
\hline Small & 4.47 & 5.16 & 6.14 & 7.95 & 90 & 75 & 72 & 60 \\
\hline Medium & 4.59 & 5.30 & 5.51 & 6.51 & 47 & 41 & 34 & 26 \\
\hline Extra-large & 6.57 & 7.34 & 7.72 & 8.50 & 22 & 19 & 16 & 12 \\
\hline Mean & 4.47 & 5.24 & 5.81 & 6.85 & 97.33 & 83.67 & 74.33 & 56.83 \\
\hline
\end{tabular}

\subsection{Economic Analysis}

Significant variation in partial budget analysis was observed in different treatment combinations (Table 10). In seed production of potato from mini tuber total variable cost (TVC) was highest in extra-large minituber when planted at $10 \mathrm{~cm}$ distance (Tk.161.88). The highest gross net return Tk. 224.09 was found in the same treatment but it BCR was 1.4 which was lower than other treatment combinations. The lowest net return Tk. 18.57 was found in under-size planted at $25 \mathrm{~cm}$ distance and its BCR was also lowest (1.5). Closer planting required more labour involvement and higher seed rate/ha which resulting high TVC and lower the BCR in breeder seed production by using mini tuber as has been reported by Mamun (2012). The result suggests that the highest economic return (9.4) would occur for the 1-4 g small minituber when planted at $15 \mathrm{~cm}$ spacing if the price per kilogram of the minitubers is equal for all sizes. Pricing compensation for larger seed sizes would need to be large for much lower production potential. Production of basic seed from minituber is very costly.

Table 10. Partial budget analysis of potato for different treatment combinations of minituber size

\begin{tabular}{|c|c|c|c|c|c|c|c|c|}
\hline \multicolumn{2}{|l|}{ Treatment } & \multirow{2}{*}{$\begin{array}{l}\text { Total material } \\
\text { cost (Tk.) }\end{array}$} & \multirow{2}{*}{$\begin{array}{l}\text { Total non-material } \\
\text { cost (Tk.) }\end{array}$} & \multirow{2}{*}{$\begin{array}{l}\text { Total variable } \\
\text { cost (Tk.) }\end{array}$} & \multicolumn{2}{|c|}{ Gross return $\left(\mathrm{Kg} / \mathrm{m}^{2}\right)$} & \multirow{2}{*}{$\begin{array}{l}\text { Net return } \\
\left(\mathrm{Tk} / \mathbf{m}^{2}\right)\end{array}$} & \multirow{2}{*}{ BCR } \\
\hline Minituber size & Planting distance & & & & Seed & Non-seed & & \\
\hline \multirow[t]{4}{*}{ Under size } & $60 \times 25$ & 5.33 & 6.75 & 12.08 & 13.01 & 5.56 & 18.57 & 1.5 \\
\hline & $60 \times 20$ & 5.60 & 6.95 & 12.55 & 15.76 & 7.62 & 23.38 & 1.9 \\
\hline & $60 \times 15$ & 5.89 & 7.15 & 13.04 & 15.57 & 8.81 & 24.38 & 1.9 \\
\hline & $60 \times 10$ & 6.58 & 7.35 & 13.93 & 18.01 & 13.90 & 31.90 & 2.3 \\
\hline \multirow[t]{3}{*}{ Pea } & $60 \times 25$ & 7.84 & 6.75 & 14.59 & 107.48 & 12.17 & 119.65 & 8.2 \\
\hline & $60 \times 20$ & 8.92 & 6.95 & 15.87 & 118.21 & 17.20 & 135.41 & 8.5 \\
\hline & $60 \times 10$ & 12.84 & 7.35 & 20.19 & 155.22 & 26.56 & 181.78 & 9.0 \\
\hline \multirow[t]{4}{*}{ Small } & $60 \times 25$ & 14.51 & 6.75 & 21.26 & 107.56 & 8.85 & 116.41 & 5.5 \\
\hline & $60 \times 20$ & 17.75 & 6.95 & 24.70 & 119.92 & 11.63 & 131.55 & 5.3 \\
\hline & $60 \times 15$ & 21.17 & 7.15 & 28.32 & 144.08 & 13.37 & 157.45 & 5.6 \\
\hline & $60 \times 10$ & 29.51 & 7.35 & 36.86 & 181.45 & 19.02 & 200.47 & 5.4 \\
\hline
\end{tabular}




\begin{tabular}{|c|c|c|c|c|c|c|c|c|}
\hline \multicolumn{2}{|l|}{ Treatment } & \multirow{2}{*}{$\begin{array}{l}\text { Total material } \\
\text { cost (Tk.) }\end{array}$} & \multirow{2}{*}{$\begin{array}{l}\text { Total non-material } \\
\text { cost (Tk.) }\end{array}$} & \multirow{2}{*}{$\begin{array}{l}\text { Total variable } \\
\text { cost (Tk.) }\end{array}$} & \multicolumn{2}{|c|}{ Gross return $\left(\mathrm{Kg} / \mathrm{m}^{2}\right)$} & \multirow{2}{*}{$\begin{array}{l}\text { Net return } \\
\left(\mathrm{Tk} / \mathrm{m}^{2}\right)\end{array}$} & \multirow{2}{*}{ BCR } \\
\hline Minituber size & Planting distance & & & & Seed & Non-seed & & \\
\hline \multirow[t]{4}{*}{ Medium } & $60 \times 25$ & 24.51 & 6.75 & 31.26 & 112.79 & 8.30 & 121.09 & 3.9 \\
\hline & $60 \times 20$ & 30.99 & 6.95 & 37.94 & 130.62 & 9.46 & 140.08 & 3.7 \\
\hline & $60 \times 15$ & 37.83 & 7.15 & 44.98 & 136.75 & 9.52 & 146.27 & 3.3 \\
\hline & $60 \times 10$ & 54.51 & 7.35 & 61.86 & 156.94 & 12.79 & 169.73 & 2.7 \\
\hline \multirow[t]{4}{*}{ Large } & $60 \times 25$ & 44.52 & 6.75 & 51.27 & 127.21 & 11.70 & 138.91 & 2.7 \\
\hline & $60 \times 20$ & 57.48 & 6.95 & 64.43 & 161.00 & 13.23 & 174.23 & 2.7 \\
\hline & $60 \times 15$ & 71.16 & 7.15 & 78.31 & 170.31 & 15.63 & 185.94 & 2.4 \\
\hline & $60 \times 10$ & 104.52 & 7.35 & 111.87 & 190.13 & 19.52 & 209.65 & 1.9 \\
\hline \multirow[t]{4}{*}{ Extra-large } & $60 \times 25$ & 64.53 & 6.75 & 71.28 & 161.96 & 14.79 & 176.75 & 2.5 \\
\hline & $60 \times 20$ & 83.97 & 6.95 & 90.92 & 179.18 & 15.66 & 194.84 & 2.1 \\
\hline & $60 \times 15$ & 104.49 & 7.15 & 111.64 & 187.80 & 15.80 & 203.61 & 1.8 \\
\hline & $60 \times 10$ & 154.53 & 7.35 & 161.88 & 207.88 & 16.21 & 224.09 & 1.4 \\
\hline
\end{tabular}

Breeder's Seed price $=30 \mathrm{Tk} / \mathrm{kg}$ and non-seed price $=10 \mathrm{Tk} . / \mathrm{kg}$

\section{Conclusion}

Breeder seed production of potato was affected by minituber size and planting distance. Larger size of minituber produced more number of tubers with increased yield when it was planted in greater distance. But, the higher seed yield potential was found in larger sized with closer planting of minituber. So, it can be concluded that pea size minituber

with $15 \mathrm{~cm}$ planting distance might have the highest economic return. However, based on the yield and net return, gross return, small size minituber at $10 \mathrm{~cm}$ planting distance may be used for cost effective production of breeders' seeds of potato.

\section{Appendixes}

Appendix 1. Meteorological conditions of the experimental site during January 2012 to December 2013

\begin{tabular}{|c|c|c|c|c|}
\hline \multirow{2}{*}{ Month } & \multicolumn{2}{|c|}{ Air Temperature $\left({ }^{\circ} \mathrm{C}\right)$} & \multirow{2}{*}{ Humidity (\%) } & \multirow{2}{*}{ Rain Fall (mm) } \\
\hline & Max. & Min. & & \\
\hline January & 21.42 & 16.77 & 89.20 & 1.68 \\
\hline February & 24.33 & 19.68 & 85.25 & 0.00 \\
\hline March & 28.81 & 24.60 & 81.61 & 13.63 \\
\hline April & 31.95 & 27.12 & 82.83 & 38.68 \\
\hline May & 31.47 & 25.89 & 83.84 & 162.43 \\
\hline June & 34.00 & 25.80 & 84.53 & 247.34 \\
\hline July & 32.19 & 25.94 & 85.07 & 363.60 \\
\hline August & 31.16 & 25.94 & 86.29 & 590.30 \\
\hline September & 31.70 & 27.47 & 86.57 & 206.46 \\
\hline October & 29.74 & 26.70 & 85.29 & 182.43 \\
\hline November & 26.60 & 22.43 & 80.47 & 8.44 \\
\hline December & 19.90 & 15.45 & 89.05 & 0.00 \\
\hline Ave./total & 28.61 & 23.65 & 85.00 & 1814.94 \\
\hline
\end{tabular}

Source: Weather station, BARI, Gazipur

Appendix 2. Meteorological conditions of the experimental site during January 2013 to December 2014

\begin{tabular}{|c|c|c|c|c|}
\hline \multirow{2}{*}{ Month } & \multicolumn{2}{|c|}{ Air Temperature $\left({ }^{\circ} \mathrm{C}\right)$} & \multirow{2}{*}{ Humidity (\%) } & \multirow{2}{*}{ Rain Fall (mm) } \\
\hline & Max. & Min. & & \\
\hline January & 15.20 & 11.58 & 90.80 & 00.0 \\
\hline February & 23.85 & 19.08 & 89.89 & 8.43 \\
\hline March & 31.16 & 26.09 & 76.70 & 29.84 \\
\hline April & 32.13 & 28.2 & 76.53 & 57.11 \\
\hline May & 31.40 & 27.90 & 82.0 & 252.23 \\
\hline June & 32.06 & 29.26 & 85.96 & 369.53 \\
\hline July & 32.32 & 27.67 & 83.45 & 269.13 \\
\hline August & 32.0 & 25.90 & 85.58 & 138.65 \\
\hline September & 30.38 & 26.53 & 89.46 & 212.65 \\
\hline October & 30.67 & 27.06 & 87.41 & 187.01 \\
\hline November & 27.76 & 23.76 & 85.66 & 00.0 \\
\hline December & 24.80 & 16.58 & 90.70 & 55.19 \\
\hline Ave./total & 29.46 & 24.81 & 85.34 & 1579.77 \\
\hline
\end{tabular}

Source: Weather station, BARI, Gazipur 


\section{References}

[1] AIS. 2014. Seed supplied by BADC in 2012-13. Krishi Diary. Agriculture Information Service, Khamarbari, Farmgate, Dhaka, Bangladesh. P.7.

[2] Akhtar, Parveen., S. J. Abbas, M. Aziz, A. H. Shah and N. Ali. 2010. Effect of Growth Behavior of Potato Mini Tubers on Quality of Seed Potatoes as Influenced by Different Cultivars. Pak. J. Pl. Sci. 16 (1): 1-9.

[3] Allen, E. J. and D. C. E. Wurr. 1992. Plant density. In: P. M. Harris (Ed.), The Potato Crop. The scientific basis for improvement. Second edition. Chapman and Hall, London, UK, pp. 292-333.

[4] Bussan, A.J., P.D. Mitchell, M.E. Copas and M.J. Drilias, 2007. Evaluation of the effect of density on potato yield and tuber size distribution. Crop Sci. 47: 2462-2472.

[5] Creamer, N.G., C.R. Crozier and M.A. Cubeta, 1999. Influence of seed piece spacing and population on yield, internal quality and economic performance of Atlantic, Superior and Snowden potato varieties in Eastern North Carolina. American J. Potato Res., 76: 257-261.

[6] El-Amin, S. M., B. Adam, E. Varis and E. Pehu. 1996. Production of seedling tubers. Experimental Agric. 32 (4): 419-426.

[7] Gopal, J., R. Kumar and G. S. Kang. 2007. The effectiveness of using a minituber crop for selection of agronomic characters in potato breeding programmes Potato Journal, 34 (1 \& 2): $145-151$.

[8] Hassanpanah D., A. A. Hosienzadeh and N. Allahyari. 2009. Evaluation of planting date effects on yield and yield components of Savalan and Agria cultivars in Ardabil region. Journal of Food, Agriculture \& Environment, 7 (3\&4): 525528.

[9] Haverkort, A. J., M. Van de Waart \& J. Marinus.1991. Field Performance of Potato Microtubers as Propagation Materials. Potato Research. 34: 353-364.

[10] Hossain, M. A., A. U. Hauque, M. S. Alam, M. Hossain, M. M. Khatun, M. M. Hasan and S. N. Begum. 2008. Disease free
Minituber Production of Potato Using Tissue Culture Methods (In Bangla), TCRC, BARI, Joydebpur, Gazipur-1701, Bangladesh. P.1.

[11] Islam, M. S., S. Moonmoon, M. Z. Islam, H. Waliullah and M. S. Hossain. 2012. Studies on Seed Size and Spacing for Optimum Yield of Potato in Northern Region of Bangladesh. Bangladesh J. Prog. Sci. \& Tech. 10(1): 113-116.

[12] Karafyllidis, D.I., D.N. Georgakis, N.I. Stavropoulos, E.X. Nianiou, and I.A. Vezyroglou. 1997. Effect of planting density and size of potato seed-minitubers on their yielding capacity. Acta Hort. 462:943-949.

[13] Kenneth, A. R. and B. A. Charlton. 2005. Effects of prenuclear minituber seed size on production of Wallowa Russet Seed. Annual Report. Klamath Experiment Station. USA. 31-38 pp.

[14] Mamun, A. A. 2012. Effect of Planting time and spacing of top shoot cutting for breeder's seed production of potato. MS thesis. BSMRAU. Gazipur-1706. 1-66 pp.

[15] Masarirambi, M. T., F. C. Mandisodza, A. B. Mashingaidze and E. Bhebhe, 2012. Influence of plant population and seed tuber size on growth and yield components of potato (Solanum tuberosum). Int. J. Agric. Biol. 14: 545-549.

[16] Rykbost, K. A. and B. A. Charlton.2004. Effects of Prenuclear Minituber Seed Size on Production of Wallowa Russet Seed. Annual Report. Klamath Experiment Station (KES), Klamath Falls, Oregon, USA. pp 38-43.

[17] Struik, P. C. 2007. The canon of potato science: Minitubers. Potato Res. 50(3-4):305-308.

[18] Sultana N and Siddique A. 1991. Effect of cut seed piece and plant spacing on the yield and profitability of potato. Bangladesh Horticulture. 19(1): 37-43.

[19] Tuku, B. T. 2000. The utilization of true potato seed (TPS) as an alternative method of potato production. Indonesian $\mathrm{J}$. Agric. Sci. 1 (2): 29-38.

[20] Zakaria, M. 2003. Induction and Performance of Potato Microtuber. Ph D Dissertation. Department of Horticulture. BSMRAU, Gazipur-1701. Bangladesh. 144-159 pp.

[21] Zkaynak E. and B. Samanci. 2006. Field performance of potato minituber weights at different planting dates. Archives of Agronomy \& Soil Scienc. 52 (3): 333-338. 